ISSN 1112-9867

Available online at

http://www.jfas.info

\title{
A STUDY ON THE EFFECT OF MACROECONOMIC VARIABLES AND FIRM CHARACTERISTICS ON THE QUALITY OF FINANCIAL REPORTING OF LISTED FIRMS IN TEHRAN STOCK EXCHANGE
}

\author{
S. Ghareli ${ }^{*}$ A. Mohammadi \\ Tabriz Branch, Islamic Azad University, Tabriz, Iran
}

Published online: 16 July 2016

\begin{abstract}
According to conducted studies, financial structure of organization was so important in its value and validity. For this purpose, managers should be aware about the variables affect the financial structure or organization and achieve an optimized financial structure using a proper attitude and scientific theories. The factors influencing on financial structure can be macroeconomic variables and specific features of organization. Macroeconomic variables in this study were Exchange rates, inflation rates, interest rates and GDP. The firm characteristics in this study included working capital, size of firm and financial leverage. The purpose of this study was to examine the effect of macroeconomic variables and firm characteristics on quality of financial reporting. In this study, Francis et al Model (2005) has been used to examine the quality of financial reporting. The statistical population was listed firms in Tehran Stock Exchange. 91 firms were selected as statistical sample using elimination method. Time period of study was 2005 to 2013. Multiple linear regression and Spearman correlation test have been used to test the hypotheses. The results showed that, the macroeconomic variables had no effect on quality of financial reporting and there was indirect and moderate correlation between GDP and quality of financial reporting. But, specific features of firm had effect on quality of financial reporting and out of variables of specific characteristic of firm except working capital, there was a significant correlation between financial leverage and size of firm with quality of financial reporting.
\end{abstract}

Author Correspondence, e-mail: Sh.Gareli67@Yahoo.Com

doi: http://dx.doi.org/10.4314/jfas.v8i2s.120 
Keywords: Specific Characteristics of Firm, Macroeconomic Variables, Quality of Financial Reporting, Size of Firm, Financial Leverage

\section{INTRODUCTION}

The main role of financial reporting is transferring the information effectively to the individual inside the organization using a valid method and in time (Norvash and Hosseini, 2009). Financial statements are main core of financial reporting containing some information about financial status and financial performance of enterprises and is presented in order to be applied by a wide range of users such as investors, creditors and government. Since, the information in financial statements is one of the most important principles to make rational decisions; therefore, users should evaluate the quality before applying financial reporting in the process of decision making (Bozorg Asl, 2001). Continuous increasing the quality of financial reporting and providing professional information is the necessity of business and professional world today. Various factors such as intra-organizational factors such as profitability, working capital and firm size and extra-organizationalfactors such as macroeconomic variables are title of our study can affect the quality of financial reporting. The effect of macroeconomic variables on capital market has been approved. Since, developing countries supply their needs through advanced countries; therefore, the changes of exchange rate is one of the most important and effective factor to settle the debt. Increasing exchange rate in one hand increases the foreign debt and on other hand increases the finished cost of products and services imported by these enterprises. Increasing the debt results in lack of liquidity and lack of liquidity has negative effect on Distribution of profits, return on equity and price index. Also, increasing the finished cost of products results in decreasing profit margin, price and stock return and finally reduces stock index and this affects the financial reporting and its quality. Interest rate is selected by investors through investment portfolio such as banking deposit and stock. According to the experiences obtained by investment return result in Iran stock market and its risk, investorsbelieve that the return obtained by investment in stock market is not sufficient despite the risky status. In other hand, Long-term bank deposit interest rates without risk in Iran caused this macroeconomic variable as a competitor to invest in stock market.

Market balance is not established based on nominal values and investors stated inflation as one of most important macroeconomic variables influencing on investment decision making. GDP is one of most effective factors in quality of financial reporting. Because, investor 
despite the awareness of consumption of private sector tries to invest in the companies that have good growth of services of product consumption. This specifies that how much is product and services consumption in public sector and how is in the future. So, this affects the disclosure of enterprises. Generally, combination of GDP components and its growth rate is important to make investment decisions (Sami, 1997)

\section{Different Approaches to Evaluate the Quality of Financial Reporting}

These approaches are divided in two classifications:

1. User's Needs: in this classification, quality of financial reporting is specified based on usefulness of financial information for users. The theoretical framework of Financial Accounting Standards Board is an initial sample of this model. The board in a conceptual statement stated that quality should be defined based on general objectives of financial reporting such as providing useful information for users to making investment decisions, validity and like this. The board then defines the qualitative characteristics to meet the needs. According to board model, qualitative features include (Prediction value, the value of verification and timeliness), and reliable (care-taking, honest and neutral expressing), comparable consistency and visibility. The board verify that, this is a mental evaluation and often a balance should be established between relevance and reliability.

2- Supporting shareholders / investors: in this classification, quality of financial information is defined for shareholders based on "complete and fair disclosure". The basic objective of earning management announced and implemented by LevittChairman of the Stock Exchange America is to support shareholder / investor. In this context, quality of financial reporting is to use clear and complete financial information to prevent misdirection and ambiguity for users. The approaches classified in classification of shareholder / investor classification have similar criteria to specify the quality of accounting principles and financial reporting (Vakili Fard and Ali Akbari, 2009)

\section{History of Study}

Medsen (2002) examined the relationship between stock return and macroeconomic variables for Members of Economic Cooperation and Development Joint using Fama Model in 1962 to 1995. In Fama Model, the variables influencing the stock return include the growth rate of national income, the first difference in interest rates, liquidity and inflation growth rates.

Medsen by estimating this model for countries of OECD concluded that inflation and interest have negative effect on stock return and liquidity and national income growth have positive effect on stock return. 
Hamp and Mac Melin (2006) in a study examined the effect of macroeconomic variables on long-term displacement in stock market. The results showed a positive relationship between industrial production, price index of consumer and short-term interest on stock return and also a negative relationship between long-term interest and stock market.

Ariotis et al (2007) in a study titled “ how enterprise's features affect the capital structure: used panel data test in Greece market and concluded a negative relationship between capital structure and interest rate and expected growth and quick ratio and there is a positive relationship between firm size and capital structure.

Rajgopal and Vonkatachalma (2011) examined the relationship between quality of financial reporting and volatility of stock return within 1962 to 2001 . They concluded that the volatility of stock return is increased by reducing the quality of profit.

Azizi (2009) in his Ph.D. thesis identified the macroeconomic variables influencing the price index of stock. Azizi examined 40 variables in both monetary and actual classifications related to price index of stock in Tehran Stock Exchange and concluded that none of the variables have important descriptive power, but 5 monetary variables such as wholesale price index, liquidity of private sector, free dollar exchange rate, the price index of construction materials and the price of a square meter building in Tehran have more explanatory power than other variables.

Hashem Kamali Rezaei (2008) examined the effect of macroeconomic variables on stock return. The macroeconomic variables of study were inflation, growth of stock index, employment growth and GDP and their effect was examined using simple regression in Tehran Stock Exchange. The results show that inflation and employment growth have no effect on stock return, but GDP (finite effect) and stock price growth affect the return.

Bidel et al (2009) followed by three previous studies examined the quality of financial reporting with investment efficiency and concluded that high quality of financial reporting, efficiency of investment in capital items results in reducing information asymmetry and factors such as improper selection of ethical danger and reduce the investment. Their findings indicate a positive or negative correlation between quality of financial reporting and low-limit investment or higher- limit investment.

Sirani and Soltan Abadi (2013) examined the relationship between firm characteristic and accounting standards in firms listed in Tehran Stock Exchange and concluded that Iran Accounting Standards are observed in high level in the enterprises under study and variables such as firm size, duration of presence the company in the Stock exchange and life of 
enterprises have no effect on observing the accounting standards. But, profitability has significant and direct effect on observing the accounting standards.

Mehrani et al (2014) in their study titled "the relationship between enterprises strategies and quality of financial reporting" founded a significant relationship between enterprises strategies and quality of financial reporting. So that, increasing the variables of enterprises strategies results in improving the index of profit quality and finally the quality of financial reporting is increased.

\section{Objectives of Study}

The results of study follow below scientific objectives:

1. The effect of macroeconomic variables on quality of financial reporting

2. The effect of specific enterprises features on quality of financial reporting

\section{Hypotheses of Study}

Below hypotheses are designed in this study based on theoretical principles and literature:

First main hypothesis: macroeconomic variables affect the quality of financial reporting.

First sub-hypothesis: exchange rate affect the quality of financial reporting.

Second sub-hypothesis: interest rate affect the quality of financial reporting.

Third sub-hypothesis: inflation rate affects the quality of financial reporting.

Fourth sub-hypothesis: economic growth affects the quality of financial reporting.

Second main hypothesis: specific characteristics of enterprise affect the quality of financial reporting.

First sub-hypothesis: working capital affect the quality of financial reporting.

Second sub-hypothesis: firm size affect the quality of financial reporting.

Third sub-hypothesis: financial leverage affect the quality of financial reporting.

\section{Methodology of Study}

The statistical data was gathered in time interval of 2005 to 2013. Due to important role of firms listed in Stock Exchange in each country, the firms listed in Tehran Stock Exchange were selected as statistical population. The reason to select these firms was due to supervision of economic organs and organization such as Ministry of Finance and Central Bank. Also, these data are reliable, because the financial statement of firms listed in Tehran Stock Exchange should be approved by a reliable accountants confirmed by Stock Exchange. The location of study was listed firms in Tehran Stock Exchange and the time interval were 2005 to 2013. In this study, systematic elimination sampling method was used to select the sample and the criteria to select the sample were as below: 
1. The fiscal year of firms should be ended in March due to scalability.

2. The firms should not stopped their activities and changed their fiscal course.

3. All data related to firms should be available.

4. The firms should be the member of banks or financial institutions (investment firms, financial dealers, holding enterprises, leasing and insurance).

5. The firms have been listed in the Stock Exchange before 2005 .

Using above criteria, 91 firms were selected as statistical sample.

\section{Data Gathering Method}

This method used library method. In this study, the data of literature, theoretical principles, history and previous studieswas gathered through librarian resources. The topic of study was gatherer by books and journals, internal and foreign thesis. The financial reports were extracted using Tadbir Pardaz software and financial information compact CD.

\section{Data Analysis Method}

In this study, Excel software was used to classify the data. After classifying the data, software such as EVIEWS, STATA and MINITAB were used to process the data and testing the hypotheses.

\section{Variables of Study and Measuring the Variables}

Variables are one of main component of study. Variable is changed in term of value and can accept different numerical values (Khaki, 2007).

In this study, below models have been used to test the hypotheses:

$\mathrm{FRQ}_{\mathrm{it}}=\alpha_{0}+\beta_{1} \mathbf{E R}_{\mathrm{it}}+\beta_{2} \mathrm{IR}_{\mathrm{it}}+\beta_{3} \mathrm{GDP}_{\mathrm{it}}+\beta_{4} \mathrm{INF}_{\mathrm{it}}+\varepsilon_{\mathrm{it}}$

$\mathrm{FRQ}_{\mathrm{it}}=\alpha_{0}+\beta_{1} \mathrm{WC}_{\mathrm{it}}+\beta_{2} \mathrm{SIZE}_{\mathrm{it}}+\beta_{3} \mathrm{LEV}_{\mathrm{it}}+\varepsilon_{\mathrm{it}}$

The variables used in this study include

\section{Independent variables}

1. Macroeconomic variables: exchange rate, interest rate, inflation rate and economic growth of central bank

Exchange rate: in this study, the continuous changes of annual exchange rate is used at the end of year and is calculated using below equation:

$$
E R F_{t}=\frac{\left(E R_{t}-E R_{t-1}\right)}{E R_{t-1}}
$$


$\mathrm{ERF}_{\mathrm{t}}$ : Volatility of exchange rate in year $\mathrm{t}$

$\mathrm{ER}_{\mathrm{t}}$ : Exchange rate at the end of year $\mathrm{t}$

$\mathrm{ER}_{\mathrm{t}-1}$ : Exchange rate at the end of year $\mathrm{t}-1$

Interest rate: is used in order to evaluate the Provisional annual interest rate of securities.

Inflation rate: is used in order to evaluate the volatility of consumer price index

Economic growth: in this study, continuous changes of GDP at the end of each year is used and is calculated using below equation:

$$
G D P F_{t}=\frac{\left(G D P_{t}-G D P_{t-1}\right)}{G D P_{t-1}}
$$

$\mathrm{GDPF}_{\mathrm{t}}$ : Volatility of GDP in year $\mathrm{t}$

$\mathrm{GDP}_{\mathrm{t}}$ : GDP at the end of year $\mathrm{t}$

$\mathrm{GDP}_{\mathrm{t}-1}$ : GDP at the end of year $\mathrm{t}-1$

\section{2- FirmCharacteristics Variables}

Working capital: in this study, working capital is used as current items.

If, current items are used:

Net working capital - (current asset -current debt) / total asset

Firm size: this variable is calculated through natural logarithm of sale amount at the end of each year using below equation:

$$
\operatorname{Size}_{i t}=\operatorname{Ln}(S
$$

Size $_{i t}$ : size of firm $i$ at the end of year $t$

$\mathrm{S}_{\mathrm{it}}$ : Sale rate of firm $\mathrm{i}$ at the end of year $\mathrm{t}$

Financial leverage: this variable is calculated through dividing total debt ratio to total asset using below equation:

$\mathrm{LEV}_{\mathrm{it}}$ : Financial leverage of firm $\mathrm{i}$ at the end of year $\mathrm{t}$

$\mathrm{TL}_{\mathrm{it}}$ : Debt ratio of firm $\mathrm{i}$ at the end of year $\mathrm{t}$

$\mathrm{TA}_{\mathrm{it}}$ : Asset rate of firm $\mathrm{i}$ at the end of year $\mathrm{t}$ 


\section{Dependent Variable}

\section{Quality of Financial Reporting}

In this study, Francis et al Model (2005) has been used to evaluate the quality of financial reporting. To measure the quality of financial reporting, the total accrual component of earnings should be calculated. According to Dechow \& dichev Model (2002), the accrual item us equal to difference between earnings and cash flow of operation

TCAi,t $=$ Ei, - CFO i,t

$\mathrm{TAi}, \mathrm{t}=$ total accrual items

Ei,t: operating profit

CFOi,t: cash flow caused by operating activities of firm $\mathrm{i}$ in year $\mathrm{t}$

In this study, the accrual items based on Francis et al Model (2005) is used to evaluate the quality of financial reporting and residual is calculated using below equation:

TCAi, $\mathrm{t}=\mathrm{a} 0+\mathrm{a} 1 \mathrm{CFOi}, \mathrm{t}-1+\mathrm{a} 2 \mathrm{CFOi}, \mathrm{t}+\mathrm{a} 3$ CFOi, $\mathrm{t}+1+\mathrm{a} 4 \quad \mathrm{REVi}, \mathrm{t}+\mathrm{a} 5$ PPEi, $\mathrm{t}+\varepsilon i, \mathrm{t}$

The criteria to measure the quality of financial reporting based on the mentioned model is absolute value of residual caused by regression. All variables should be divided on total asset at the end of fiscal year for standardization.

In the above model:

$\mathrm{TCA}_{\mathrm{it}}$ : Total accrual item in year $\mathrm{t}$ for firm $\mathrm{i}$

$\mathrm{CFO}_{\mathrm{it}}$ : The cash flow caused by operating activities in year $\mathrm{t}$ for firm $\mathrm{i}$ (Mamoudabad et al, 2012)

REV (changes of firm sale) is to control the changes in discretionary accruals caused by changing in situation

PPE (Gross of property, equipment and Machinery)

All variables in the model are divided by book value of assets.

\section{Descriptive Statistic of Data}

In order to recognize the nature of the society under study and also to recognize the variables, it is necessary to explain these data before statistical data analysis. Also, statistical data analysis is a step to recognize the pattern and a basic to explain the relationship between the variables used in this study. Before examining the hypotheses testing, the variables are examined. This table shows indices to explain the variables of study. Average, mean, standard deviance, maximum and minimum are calculated in descriptive analysis of data. 
Table 1. Descriptive Statistic

\begin{tabular}{|c|c|c|c|c|c|c|c|c|}
\hline & $\begin{array}{c}\text { Workin } \\
\text { g } \\
\text { capital }\end{array}$ & $\begin{array}{c}\text { Fir } \\
\text { m } \\
\text { size }\end{array}$ & $\begin{array}{c}\text { Financi } \\
\text { al } \\
\text { leverage }\end{array}$ & $\begin{array}{l}\text { Intere } \\
\text { st rate }\end{array}$ & $\begin{array}{l}\text { Inflatio } \\
\text { n rate }\end{array}$ & $\begin{array}{l}\text { Economi } \\
\text { c growth }\end{array}$ & $\begin{array}{c}\text { Quality } \\
\text { of } \\
\text { financia } \\
\text { l } \\
\text { reportin } \\
\mathrm{g}\end{array}$ & $\begin{array}{c}\text { Exchang } \\
\text { e rate }\end{array}$ \\
\hline Average & 0.34 & $\begin{array}{c}12.7 \\
7\end{array}$ & 0.611 & 0.09 & 0.16 & 0.02 & 0.063 & 0.05 \\
\hline Mean & 0.34 & $\begin{array}{c}12.7 \\
5\end{array}$ & 0.63 & 0.09 & 0.12 & 0.04 & 0.046 & 0.03 \\
\hline $\begin{array}{c}\text { Maximu } \\
\text { m }\end{array}$ & 0.93 & $\begin{array}{c}16.6 \\
7\end{array}$ & 1.34 & 0.14 & 0.31 & 0.08 & 0.02 & 0.18 \\
\hline $\begin{array}{c}\text { Minimu } \\
\text { m }\end{array}$ & -0.87 & 5.25 & 0.01 & 0.06 & 0.03 & -0.07 & 0.00 & -0.03 \\
\hline $\begin{array}{c}\text { Standar } \\
\text { d } \\
\text { deviance }\end{array}$ & 0.21 & 1.31 & 0.19 & 0.02 & 0.082 & 0.04 & 0.06 & 0.06 \\
\hline $\begin{array}{c}\text { Skewnes } \\
\text { s }\end{array}$ & -1.13 & $\begin{array}{c}- \\
0.28\end{array}$ & -0.52 & 0.50 & 0.33 & -0.82 & 5.06 & 0.80 \\
\hline Kurtosis & 7.61 & 4.48 & 3.30 & 1.82 & 2.17 & 2.67 & 55.23 & 2.83 \\
\hline Number & 819 & 819 & 819 & 819 & 819 & 819 & 819 & 819 \\
\hline
\end{tabular}

Normality of variables (especially dependent variable in regression model) is the first provision to do all parametric tests. Jarque and Bera Test has been used to examine the normality of variables. Results of Jarque and Bera Test is shown in Table 4-3. 
Table 2. Results of Jarque and Bera Test

\begin{tabular}{|c|c|}
\hline Variables & Significant Level \\
\hline $\begin{array}{c}\text { Exchange rate } \\
\text { reporting }\end{array}$ & 0.000 \\
\hline Economic growth & 0.000 \\
\hline Inflation rate & 0.000 \\
\hline Interest rate & 0.000 \\
\hline Financial leverage & 0.000 \\
\hline Firm size & 0.000 \\
\hline Working capital & 0.000 \\
\hline
\end{tabular}

Probability level of all variables is less than $5 \%$ and this indicates that none of variables have normal distribution. One of the normal methods of converting is Johnson method at Minitab software, which is shown the results in the table below for the quality of financial reporting

Table 3. Results of Johnson Test

\begin{tabular}{|c|c|c|}
\hline Variable & Significant level & Johnson Test \\
\hline $\begin{array}{c}\text { Quality of Financial } \\
\text { Reporting }\end{array}$ & 0.26 & 0.457 \\
\hline
\end{tabular}

In this case, significant level is more than 0.05; therefore, variable of quality of financial reporting has normal distribution.

\section{Correlation Coefficient}

Correlation coefficient is one of the criterion used to determine the correlation between two variables. Correlation coefficient shows the intensity of linearity correlation and kind of correlation (direct or reverse) between two variables. In this study, qualitative variables are used; therefore, Spearman Correlation Coefficient has been used. The correlation coefficient between quality of financial reporting and exchange rate is 0.02 and this indicates that the correlation between these two variables is 0.02 . This correlation is positive; i.e., increasing exchange rate results in increasing quality of financial reporting, but this correlation is too weak. In the correlation coefficient Table, the significance level of correlation between 
variables are inserted. $\mathrm{H} 0$ indicates that there is no significant correlation between two variables and $\mathrm{H} 1$ indicates that there is a correlation between two variables. In correlation coefficient table, there is significant correlation between economic growth and exchange rate, this significance level is less than 0.05 .

Table 4. Correlation Coefficient Table

\begin{tabular}{|c|c|c|c|c|c|c|c|c|}
\hline & $\begin{array}{l}\text { Workin } \\
\text { g capital }\end{array}$ & $\begin{array}{l}\text { Firm } \\
\text { size }\end{array}$ & $\begin{array}{c}\text { Financia } \\
1 \\
\text { leverage }\end{array}$ & $\begin{array}{l}\text { Interes } \\
\text { t rate }\end{array}$ & $\begin{array}{l}\text { Inflatio } \\
\text { n rate }\end{array}$ & $\begin{array}{l}\text { Economi } \\
\text { c growth }\end{array}$ & $\begin{array}{l}\text { Quality } \\
\text { of } \\
\text { financial } \\
\text { reportin } \\
\text { g }\end{array}$ & $\begin{array}{c}\text { Exchang } \\
\text { e rate }\end{array}$ \\
\hline $\begin{array}{c}\text { Exchang } \\
\text { e rate }\end{array}$ & & & & & & & & 1 \\
\hline $\begin{array}{l}\text { Quality } \\
\text { of } \\
\text { financial } \\
\text { reporting }\end{array}$ & & & & & & & 1 & $\begin{array}{l}0.02 \\
0.47\end{array}$ \\
\hline $\begin{array}{l}\text { Economi } \\
\text { c growth }\end{array}$ & & & & & & 1 & $\begin{array}{c}-0.03 \\
0.37\end{array}$ & $\begin{array}{l}-0.34 \\
* 0.00\end{array}$ \\
\hline $\begin{array}{l}\text { Inflation } \\
\text { rate }\end{array}$ & & & & & 1 & $\begin{array}{l}-0.15 \\
0.00\end{array}$ & $\begin{array}{l}-0.02 \\
0.54\end{array}$ & $\begin{array}{l}-0.28 \\
* 0.00\end{array}$ \\
\hline $\begin{array}{c}\text { Interest } \\
\text { rate }\end{array}$ & & & & $\begin{array}{ll}11 \\
\end{array}$ & $\begin{array}{c}0.11 \\
* 0.001\end{array}$ & $\begin{array}{l}\mathbf{- 0 . 8 3} \\
* 0.00\end{array}$ & $\begin{array}{l}0.02 \\
0.52\end{array}$ & $\begin{array}{c}0.41 \\
* 0.00\end{array}$ \\
\hline $\begin{array}{l}\text { Financial } \\
\text { leverage }\end{array}$ & & & $\mathbf{1}$ & $\begin{array}{c}-0.001 \\
0.97\end{array}$ & $\begin{array}{c}-0.02 \\
0.45\end{array}$ & $\begin{array}{c}-0.007 \\
0.84\end{array}$ & $\begin{array}{c}0.15 \\
* 0.00\end{array}$ & $\begin{array}{c}0.042 \\
0.22\end{array}$ \\
\hline Firm size & & 1 & $\begin{array}{c}-0.003 \\
0.91\end{array}$ & $\begin{array}{c}0.21 \\
* 0.00\end{array}$ & $\begin{array}{l}0.03 \\
0.30\end{array}$ & $\begin{array}{l}-0.21 \\
* 0.00\end{array}$ & $\begin{array}{r}-0.08 \\
* 0.01\end{array}$ & $\begin{array}{c}0.12 \\
* 0.00\end{array}$ \\
\hline $\begin{array}{l}\text { Working } \\
\text { capital }\end{array}$ & 1 & $\begin{array}{c}0.00 \\
3 \\
0.91\end{array}$ & -1 & $\begin{array}{c}0.001 \\
0.97\end{array}$ & $\begin{array}{l}0.02 \\
0.45\end{array}$ & $\begin{array}{c}0.007 \\
0.84\end{array}$ & $\begin{array}{l}-\mathbf{0 . 1 5} \\
* 0.00\end{array}$ & $\begin{array}{l}-0.04 \\
0.22\end{array}$ \\
\hline
\end{tabular}




\section{Analysis of Hypotheses}

\section{Results of Analysis for First Main Hypothesis}

First Main Hypothesis: Macroeconomic variables affect the quality of financial reporting.

First sub-hypothesis: exchange rate affect the quality of financial reporting.

Panel data was used based on significance level of Limer Test and random effect was used to analyze the results of test based on significance level of Hausmann Test.

Table 5. Results of Test for hypothesis 1-1

\begin{tabular}{|c|c|c|c|}
\hline $\begin{array}{c}\text { Significance } \\
\text { Level }\end{array}$ & Statistic t & Coefficient & Variables \\
\hline 0.00 & 5.68 & 0.12 & Exchange rate \\
\hline 0.93 & -0.08 & -0.003 & Intercept \\
\hline \multicolumn{2}{|c|}{0.002} & & \multicolumn{2}{|c|}{ Coefficient of determination } \\
\hline \multicolumn{2}{|c|}{1.84} & \multicolumn{2}{|c|}{ Durbin-Watson test } \\
\hline
\end{tabular}

According to above table:

Coefficient of determination is equal to $0.2 \%$ and this indicates that the dependent variable is dependent on independent variables in the model $0.2 \%$ and to other variables $99.8 \%$ that have not been noted in the above model.

Durbin-Watson statistic is equal to 1.84 , if this value is 1.5 to 2.5 , there is lack of first autocorrelation between residuals. The basic of decision making to reject or accept the first hypothesis is significance level of exchange rate. Significance level is 0.000 that is less than 0.05. So, first hypothesis is accepted at confidence level of 5\%. This effect is positive; i.e., quality of financial reporting is increased by increasing the exchange rate.

Second sub-hypothesis: interest rate affect the quality of financial reporting.

According to table 4-9, Panel data and random effect was used to analyze the results of test based on significance level of Hausmann Test. 
Table 6. Results of Test for Second sub-hypothesis

\begin{tabular}{|c|c|c|c|}
\hline $\begin{array}{c}\text { Significance } \\
\text { Level }\end{array}$ & Statistic t & Coefficient & Variables \\
\hline 0.01 & 2.57 & 1.50 & Interest rate \\
\hline 0.04 & -2.00 & -0.12 & Intercept \\
\hline & 0.33 & & \multicolumn{2}{|c|}{ Coefficient of determination } \\
\hline \multicolumn{2}{|c|}{2.10} & \multicolumn{2}{|c|}{ Durbin-Watson test } \\
\hline
\end{tabular}

According to above table:

Coefficient of determination is equal to $33 \%$ and this indicates that the dependent variable is dependent on independent variables in the model $33 \%$ and to other variables $67 \%$ that have not been noted in the above model.

Durbin-Watson statistic is equal to 2.10 , if this value is 1.5 to 2.5 , there is lack of first autocorrelation between residuals. The basic of decision making to reject or accept the first hypothesis is significance level of interest rate. Significance level is 0.000 that is less than 0.05. So, first hypothesis is accepted at confidence level of $5 \%$. This effect is positive; i.e., quality of financial reporting is increased by increasing the interest rate. In other word, interest rate has significant and positive effect on quality of financial reporting.

Fourth sub-hypothesis: Inflation rate affect the quality of financial reporting.

According to Limer Test, Panel data and random effect was used to analyze the results of test based on significance level of Hausmann Test.

Table 7. Results of Test for Fourth sub-hypothesis

\begin{tabular}{|c|c|c|c|}
\hline $\begin{array}{c}\text { Significance } \\
\text { Level }\end{array}$ & Statistic t & Coefficient & Variables \\
\hline 0.14 & -1.47 & -0.27 & Inflation rate \\
\hline 0.13 & 1.49 & -0.05 & Intercept \\
\hline & 0.33 & & Coefficient of determination \\
\hline & 2.09 & \multicolumn{2}{|c|}{ Durbin-Watson test } \\
\hline
\end{tabular}


According to above table:

Coefficient of determination is equal to $33 \%$ and this indicates that the dependent variable is dependent on independent variables in the model $33 \%$ and to other variables $77 \%$ that have not been noted in the above model.

Durbin-Watson statistic is equal to 2.09 , if this value is 1.5 to 2.5 , there is lack of first autocorrelation between residuals. The basic of decision making to reject or accept the first hypothesis is significance level of inflation rate. Significance level is 0.14 that is greater than 0.05. So, first hypothesis is rejected. In other word, inflation rate has no significant effect on quality of financial reporting.

Fourth sub-hypothesis: economic growth affect the quality of financial reporting.

According to Limer Test, Panel data and random effect was used to analyze the results of test based on significance level of Hausmann Test.

Table 8. Results of Test for Fourth sub-hypothesis

\begin{tabular}{|c|c|c|c|}
\hline $\begin{array}{c}\text { Significance } \\
\text { Level }\end{array}$ & Statistic t & Coefficient & Variables \\
\hline 0.07 & -1.78 & -0.69 & Economic Growth \\
\hline 0.16 & 1.40 & 0.02 & Intercept \\
\hline & 0.33 & & Coefficient of determination \\
\hline & 2.09 & \multicolumn{2}{|c|}{ Durbin-Watson test } \\
\hline
\end{tabular}

According to above table:

Coefficient of determination is equal to $33 \%$ and this indicates that the dependent variable is dependent on independent variables in the model $33 \%$ and to other variables $77 \%$ that have not been noted in the above model.

Durbin-Watson statistic is equal to 2.09 , if this value is 1.5 to 2.5 , there is lack of first autocorrelation between residuals. The basic of decision making to reject or accept the first hypothesis is significance level of economic growth. Significance level is 0.07 that is greater than 0.05 . So, first hypothesis is rejected. In other word, economic growth has no significant effect on quality of financial reporting. 


\section{Results of Analysis for second Main Hypothesis}

First Main Hypothesis: specific characteristics of firm affect the quality of financial reporting.

First sub-hypothesis: working capital affect the quality of financial reporting.

Panel data was used based on significance level of Limer Test and random effect was used to analyze the results of test based on significance level of Hausmann Test.

Table 9. Results of Test for second Main Hypothesis

\begin{tabular}{|c|c|c|c|}
\hline $\begin{array}{c}\text { Significance } \\
\text { Level }\end{array}$ & Statistic t & Coefficient & Variables \\
\hline 0.00 & -3.33 & -0.54 & $\begin{array}{c}\text { Specific } \\
\text { Characteristics Of } \\
\text { Firm }\end{array}$ \\
\hline 0.00 & 4.65 & 0.20 & Intercept \\
\hline \multicolumn{2}{|c|}{0.013} & \multicolumn{2}{|c|}{ Coefficient of determination } \\
\hline \multicolumn{2}{|c|}{1.85} & \multicolumn{2}{|c|}{ Durbin-Watson test } \\
\hline
\end{tabular}

According to above table:

Coefficient of determination is equal to $1.3 \%$ and this indicates that the dependent variable is dependent on independent variables in the model $1.3 \%$ and to other variables $98.7 \%$ that have not been noted in the above model.

Durbin-Watson statistic is equal to 1.85 , if this value is 1.5 to 2.5 , there is lack of first autocorrelation between residuals. The basic of decision making to reject or accept the first hypothesis is significance level of working capital. Significance level is 0.000 that is less than 0.05. So, first hypothesis is accepted at confidence level of 5\%. This effect is negative; i.e., quality of financial reporting is decreased by increasing the exchange rate. So, this hypothesis is confirmed. In other word, working capital has significant and negative effect on quality of financial reporting.

Second sub-hypothesis: firm size affect the quality of financial reporting.

According to Limer Test, Panel data and random effect was used to analyze the results of test based on significance level of Hausmann Test. 
Table 10. Results of Test for Second sub-hypothesis

\begin{tabular}{|c|c|c|c|}
\hline $\begin{array}{c}\text { Significance } \\
\text { Level }\end{array}$ & Statistic t & Coefficient & Variables \\
\hline 0.45 & -0.75 & 0.001 & Firm size rate \\
\hline 0.00 & 3.40 & 0.08 & Intercept \\
\hline & 0.31 & & \multicolumn{2}{|c|}{ Coefficient of determination } \\
\hline \multicolumn{2}{|c|}{2.03} & \multicolumn{2}{|c|}{ Durbin-Watson test } \\
\hline
\end{tabular}

According to above table:

Coefficient of determination is equal to $31 \%$ and this indicates that the dependent variable is dependent on independent variables in the model $31 \%$ and to other variables $69 \%$ that have not been noted in the above model.

Durbin-Watson statistic is equal to 2.03 , if this value is 1.5 to 2.5 , there is lack of first autocorrelation between residuals. The basic of decision making to reject or accept the first hypothesis is significance level of firm size. Significance level is 0.45 that is greater than 0.05. So, first hypothesis is rejected. In other word, firm size has no significant effect on quality of financial reporting.

Third sub-hypothesis: financial leverage affect the quality of financial reporting.

According to Limer Test less than significance level of 0.05, Panel data and random effect was used to analyze the results of test based on significance level of Hausmann Test greater than 0.05 .

Table 11. Results of Test for Third sub-hypothesis

\begin{tabular}{|c|c|c|c|}
\hline $\begin{array}{c}\text { Significance } \\
\text { Level }\end{array}$ & Statistic t & Coefficient & Variables \\
\hline 0.00 & 3.33 & 0.54 & $\begin{array}{r}\text { Financial } \\
\text { Leverage }\end{array}$ \\
\hline 0.01 & -2.54 & -0.34 & Intercept \\
\hline & 0.01 & Coefficient of determination \\
\hline & 1.85 & \multicolumn{2}{|c|}{ Durbin-Watson test } \\
\hline
\end{tabular}


According to above table:

Coefficient of determination is equal to $1 \%$ and this indicates that the dependent variable is dependent on independent variables in the model $1 \%$ and to other variables $99 \%$ that have not been noted in the above model.

Durbin-Watson statistic is equal to 1.85 , if this value is 1.5 to 2.5 , there is lack of first autocorrelation between residuals. The basic of decision making to reject or accept the first hypothesis is significance level of financial leverage. Significance level is less than 0.05 . So, this effect is positive; i.e., quality of financial reporting is increased by increasing the interest rate. So, this hypothesis is confirmed.

\section{Results of Study}

In the first main hypothesis, the effect of macroeconomic variables such as exchange rate, interest rate, inflation rate and GDP on the quality of financial reporting has been examined. According to results, exchange rate and interest rate have singificnat effect on quality of financial reporting and inflation and GDP have no significant effect. The results of this study is consistent to the study of Robert Gi (2008), Kalno et al (2009), Rajgopal and vonkatachalma (2011), Modarres and Hesarzadeh (2008), Bidel et al (2009), Sirani and Soltan abadi (2013), Mehrani et al (2014) and Rezaei and Garkaz (2014).

In second main hypothesis, the effect of firm characteristics such as working capital, firm size and financial leverage on quality of financial reporting. The results of regression test shows that the variable of working capital has significant and negative effect and financial leverage has significant and positive effect on quality of financial reporting. Firm size has no effect on quality of financial reporting. The results of this study is not consistent to the study of Robert Gi (2008), Kalno et al (2009), Rajgopal and vonkatachalma (2011), Modarres and Hesarzadeh (2008), Bidel et al (2009), Sirani and Soltan abadi (2013).

Quality of financial reporting is increasing by increasing interest rate and exchange rate. Macroeconomic factors such as inflation, exchange rate and interest rate will result in political and economic instability. In inflation situation, nominal profit of a firm is increased without increasing actual profitability, exchange rate and interest rate is increased and this results in decreasing stock price. To compensate this decrease, managers increase quality of financial reporting to maintain their validity. Big companies usually have foreign controlling systems and strong corporate governance that access to high quality services of auditing firms and maintain their validity. The effect of firm size on the quality of financial reporting has not been approved in this study; therefore, it is recommended to do a study to control the factors 
directly or indirectly affect the quality of financial reporting. Working capital has significant and negative effect on quality of financial reporting. Higher working capital, increases the manipulation in the accounts and quality of financial reporting is decreased. So, it is recommended to beneficiaries to pay attention to working capital in the reporting. Financial leverage ha significant and positive effect on quality of financial reporting. Managers manipulate the accounting to decrease representative costs, when the debt-to net asset ratio is low. So, it is recommended to beneficiaries to pay more attention to accounting reports, when the quality of reports is low. In order to use the results, below recommendations are presented to researchers and readers:

1. It is recommended to do study in longer periods to obtain desirable results.

2. In a firm, various factors such as the factors related to auditors and board of director can affect the quality of financial reporting. So, it is recommended to examine the effect of board of director characteristic (financial expert, age, working experience, education and other variables), auditors (size of auditing firm, expert of auditors and other variables on quality of financial reporting.

\section{REFERENCES}

- Piri, M and Sabouhi, M, "The effect of exchange rate volatility on export prices of agricultural products case study of Iranian saffron" .sixth agricultural economic conference, 2007.

- Peivand, $\mathrm{M}$ and Khorram, F. "The importance of corporate governance and interrelationships of the audit committee, internal audit and independent auditors to improve the quality of financial reporting." auditor. . 2013, No. 69. PP. 118-25.

- Jannesari, S. A. "The effect of capital working on profitability of small to medium sized enterprises ». Auditor, 2012, 58: 1-9.

- Heidari, H. and Bashiri, S. "Examinethe relationship between uncertainty and real exchange rate and stock price index." Journal of Economic Modeling . 2013, 9: 72-80.

- Davidson, P. "Grand theory of Keynesian" translated by Ahmed Saif, Etemad Newspaper, 1994.

- Rashidi, M. "Risk management of Exchange rate fluctuation and interest." Banking Institute, Tehran, 1999.

- Razavi, Mortezz, 2013. "What is inflation?" Personal blog. Rahnamye Roodposhti, Fereidoon and Amir Hossein, Zahra. 2010. "The use of 
economic leverage in order to assess the impact of macroeconomic variables on corporate performance." Journal of Financial Studies. No. VII.

- Zavari Rezaee, Akbar, 2011. "Gross domestic product (GDP) » Accounting and Financial Management Blogs

- Shokri, Atefeh. 2011. "What is inflation" online. tebyan Library.

- Karimi, Saeed. 2011. "Interest rates". Baqer Institute

- Kafshgari Jelodar, Hossein, 2002. "Factors affecting the exchange rate," Baqer institute

- Mahmoudian, Yaghoob, 2011. "Usury, interest rates and credit rates." Resalat newspaper.

- Modarres, Ahmad and Hesarzadeh, Reza. 2008. "Financial reporting quality and investment efficiency." Quarterly Stock Exchange. First year, NO. 2 Pp. 85-116

- Yavari, K. "The effect on the industry's trade and currency policies". Business Studies and Research. $2005: 117-123$.

- Yaghoob N A, Vakili H and Babaei, A R. "The relationship between working capital management and profitability of listed firms in Tehran Stock Exchange." Journal of Financial Engineering and portfolio management. 2010 ,(2): Pp. 117-137.

- Yousefi, G, investigating the relationship between intellectual capital in the insurance industry of market orientation, a master's degree, Islamic Azad University, Sanandaj, 2011.

- Amini AR, Darani M, Afshani M, Amini Z. "Effectiveness of Marketing Strategies and Corporate Image on Brand Equity as a Sustainable Competitive Advantage",interdisciplinary journal of contemporary research in business, 2012, Vol.4,No.2,pp.192-205.

- Baldauf, A., Cravens, D. W., and Wayner, U; "Examining Determinants ofExport", Journal of World Business, 2000, 35: 61-79.

- Cambra-Fierro, J.J., Hart, S., Polo-Redondo, Y., Fuster-Mur, A.Market and learning orientation in times of turbulence: relevancequestioned? An analysis using a multicase study. Quality \& Quantity, 2012, 46 (3): 855-871.

- Chakravorti B, finding competitive advantagein adversity, harvard business review, november, 2010, : 102-108. 
- Cicic, M., Patterson, P., and Shoham, I; "Antecedent ofInternationalPerformance", European Journal of Marketing, 2002, 39: 13-18.

- Cook,WD., Bala, K., performance measurement and classification, data in DEA: input-oriented model,OMEA. The international journal of management science, 52, pp.35-39, 2007.

- Dechow P. I Dichev. "The quality of accruals and earnings: The role ofaccrual estimation errors". The Accounting Review 77 Supplement 2002, : 35-59.

- Deshpandé, R., Farley, J. U., and Webster, F. E., Jr., Corporateculture,customer orientation, and innovativeness in Japanese firms: AQuadrate Analysis, Journal of Marketing, 57, pp. 23-27, 1993.

- Dodd, C. 2005. Export Market Orientation and Performance: An Analysisof Australian Exporters, ANZMAX 2005 conference: Marketing ininternational and cross-cultural environments, Retrieved fromhttp://www.anzmac.org/conference_archive/2005/cd-site/pdfs/9- Marketing-IntC-Cultural-Env/9-Dodd.pdf

- Helfert. G. 2006. How does market orientation affect business relationship? Institute for innovation and technology.

- Hill, c.w.l, Jones, G.R, 1998, Strategic Management Theory, lst ed, Houghton Mifflin Company, U.S.A.

- Hill, c.w.1, Jones, G.R, 2007, Strategic management theory, Houghton Mifflin Company. NewYork.

- Homburg, C., Krohmer, H., Workman, J., A strategyimplementation perspective of market orientation, Journal of BusinessResearch, PP. 1331-40, 2004.

- Hoskisson, R., Hitt, M.,Wan,W.,Yiu,D.,Theory and research in strategic management: Swings of a pendulum,Journal of Management, 25, pp.417-456, 1999.

- Hurley, R. F., Hult, G. T., Innovation, market orientation, andorganizational learning: an integration and emprical examination, Journal of Marketing, PP. 42-54. 1998.

- Panigyrakis, G., \& Theodoridis, P. Market orientation and performance: an empirical investigation in the rrtail industry in Greece, Journal of Retailing and Consumer Services, 2007, 14: 137-149.

- Pelham, A., \& Wilson, D., A longitudinal study of the impact ofmarket structure, firm structure, strategy and market orientation culture ondimensions of small-firm performance, Journal of Academy of MarketingScience, PP. 27-43, 1996. 


\section{How to cite this article:}

Ghareli S, Mohammadi A. A study on the effect of macroeconomic variables and firm characteristics on the quality of financial reporting of listed firms in tehran stock exchange. J. Fundam. Appl. Sci., 2016, 8(2S), 1777-1797. 